\title{
Chief Executive Background Characteristics and Environmental Scanning Emphasis: An Empirical Investigation
}

\author{
Arifin Angriawan \\ Purdue University-Calumet • Hammond, IN \\ Michael Abebe
}

The University of Texas-Pan American • Edinburg, Texas

\section{Abstract}

This study empirically examined the relationship among Chief Executive Officer's (CEO) industry tenure, intrapersonal functional diversity and the level of environmental scanning emphasis among 90 manufacturing firms in the computer and food processing industries. Drawing from the managerial cognition and upper echelons theories, we hypothesized that CEOs who have diverse intrapersonal functional background (generalists) and longer single industry tenure are more likely to emphasize scanning both the task and general industry environments. Our findings generally support a positive relationship between the length of industry tenure, intrapersonal functional diversity and environment scanning emphasis. Implications for further strategic decision-making research are discussed.

\section{Introduction}

There is a general understanding among strategic management scholars that environmental scanning constitutes a preliminary step toward an effective strategy formulation process (Hambrick, I982; Daft, Sormunen \& Parks, 1988; Garg, Walters \& Priem, 2003). Aguilar (1967) defines environmental scanning as the process of gathering "information about events and relationships in a company's outside environment, the knowledge of which would assist top management in its task of charting the company's future course of action" (p.l). Past environmental scanning research has mainly been anchored in the organizational adaptation and strategic choice perspectives (Miles \& Snow, 1978; Child, 1972) that emphasize the active role top executives play in analyzing and interpreting wide-ranging information about the business environment (Kiesler \& Sproull, 1982; Jackson \& Dutton, 1988; Thomas, Clark \& Gioia, 1993; Garg et al., 2003). Much of the scholarly work in the scanning and strategic decision-making literatures focus on the Chief Executive Officer's (CEO) primary responsibility in orchestrating systematic environmental 
scanning, interpretation and strategic action (e.g. Daft \& Weick, 1984; Thomas, Litschert and Ramaswamy, 1993; Garg et al., 2003).

Despite such a significant role chief executives play in the environmental scanning process, there has been limited research that focuses on their background characteristics as a potential predictor of environmental scanning behaviors (Hambrick, 1981; Sutcliffe, 1994; Cho, 2006 are the exceptions). In this study, we argue that examining chief executives' characteristics is particularly important for a number of reasons. First, since CEOs face numerous constraints including 'bounded rationality' (March \& Simon, 1958) and significant resource limitations within the organization context (Garg et al., 2003); their selective perception of external environmental stimuli largely depends on their professional background, experiences and idiosyncrasies that in turn determine their strategic choice (Hambrick \& Mason, 1984). Accordingly, by empirically examining the role of CEO's background characteristics, we will be able to enhance our understanding of not only the environmental scanning process but also the overall strategic formulation and strategic decision-making. Second, we also believe that by studying CEO background characteristics, we will be able to focus on the view of top managers (and especially the chief executive) as the "information processing center" of the organization (Haleblian \& Finklestein, 1993). In this study, we explicitly make the assumption that a significant amount of organizational level environmental scanning and interpretation is made by the senior management and specifically by the CEO (Aguilar, 1967; Daft \& Weick, 1984; Garg et al., 2003).1 Hence, we believe that examining the background characteristics of the CEO helps to better understand environmental scanning emphasis and ultimately the nature of strategic decision-making.

Consequently, our argument focuses on CEO's industry tenure and intrapersonal functional diversity and their possible influence on narrow (task environment) or broad (general environment) scanning emphasis. These two CEO background characteristics are specifically selected for two major reasons: first, an extensive scholarly work in the upper echelons and strategic decision-making literatures (see Finklestein \& Hambrick, 1996 and Carpenter, Geletkanycz, \& Sanders, 2004 for extensive review) has empirically shown that executives' background characteristics influence their attention, information search and decision-making patterns. Specifically, a number of upper echelons studies in the past (e.g. Finklestein \& Hambrick, 1990; Carpenter \& Frederickson, 2001; Carpenter, 2002) have empirically examined executives' tenure, functional background and educational level as predictors of various organizational outcomes. Hence, we seek to build on this established literature stream and argue that studying these particular constructs in the context of environ- 
mental scanning could have a theoretically meaningful contribution to the extant literature. Second, since these two particular constructs have not been effectively addressed by the extant scanning literature, we believe that we can contribute to our understanding of environmental scanning behaviors as it relates to executives' background characteristics. Accordingly, our central research question is: "Is there a relationship among $\mathrm{CEO}$ background characteristics (i.e. industry tenure and intrapersonal functional diversity) and the extent of environmental scanning emphasis?" In other words, does the length of industry tenure and functional background diversity (generalists or specialists) of executives relate to the scope (narrow vs. broad) of environmental scanning emphasis? We draw from the managerial cognition (Walsh, 1995) and Upper Echelons (Hambrick \& Mason, 1984; Hambrick, 2007) theoretical frameworks in order to address this research question.

\section{Theory and Hypothesis Development}

The main focus of this study is an empirical examination of the relationship between CEO background characteristics and environmental scanning emphasis. Since we are arguing that the nature and extent of industry tenure and intrapersonal functional background influence how CEOs scan and pay attention to the external business environment, we specifically draw from the managerial cognition and upper echelon/strategic leadership literatures. Our theoretical focus, therefore, is explaining the cognitive attributes associated with industry tenure and intrapersonal functional background. In doing so, we seek to establish the theoretical framework that explains how these two predictors possibly influence CEO environmental scanning emphasis. In the following sections, we will discuss in detail the general arguments of these two theoretical frameworks and specifically develop theoreticallydriven hypotheses.

\section{Executive Cognition Perspective}

The executive cognition perspective generally argues that executives often operate within the limits of bounded rationality and make decisions based on their subjective representation of the environment ( Simon, 1959; Neisser, 1976; Hambrick \& Mason, 1984; Walsh, 1995). Such subjective representations of the environment are also called strategic schemas (Nadkarni \& Narayanan, 2007), cognitive bases (Hambrick \& Mason, 1984), or, in general, knowledge structures. Walsh (1995) defined knowledge structures as "mental templates consisting of organized knowledge about an information environment that enables interpretation and action in that en- 
vironment" (p.286). Executives utilize their previously developed knowledge structures to process most of the information except novel information (Walsh, 1995) or the one that is relevant to goal achievement (Fiske \& Taylor, 1991; Sutcliffe \& Huber, 1998). Previous researchers have identified two distinct features of knowledge structures: complexity and focus (Baum \& Wally, 2003; Eden, Ackermann, \& Cropper, 1992; Nadkarni \& Narayanan, 2005). Complexity refers to the content of knowledge structures in terms of variety of concepts and connectedness of these concepts (Walsh, 1995). Focus refers to the extent that a knowledge structure is centralized around a few core schemas (Nadkarni \& Narayanan, 2007). For example, the complexity of an executive's knowledge structure of the environment depends on the numbers of task and general environment factors contained in the schema as well as his or her understanding of the relationships among these factors. Focus refers to the dominating factors in the knowledge structure. In scanning literature, for example, task environment rather than general environment is considered to be the focus of executives' knowledge structure (Daft, Sormunen, \& Parks, 1988; Sawyerr, 1993).

Executives' knowledge structures continue to evolve as their experiences with the external business environment increase (Daft \& Weick, 1984; Fiske \& Taylor, 1991; Nadkarni \& Barr, 2008). Previous researchers have also argued that dominant knowledge structures could be self-reinforcing (Janis, 1972; Neisser, 1976; Weick, 1979). Executives utilize previously developed knowledge structures to process environmental information which further reinforce the knowledge structure. This reinforced knowledge structure is then used to process similar information. This process will go on as a self-reinforcing process and could sometimes be dysfunctional. For example, executive focus on task environment could encourage a disproportionate emphasis on information processing related to major aspects of the task environment (such as customer, competitor and supplier segments) at the expense of the general environment.

On the other hand, the executive cognition literature has also studied the benefits of complex knowledge structures. For example, McNamara, Luce and Tompson (2002) found a positive relationship between complexity of top executives' strategic group knowledge structures and subsequent firm performance. They argued that executives with complex knowledge structures have more cognitive dimensions that can be used to understand and deal with competitors and uncertainties. Nadkarni and Narayanan (2007) found positive relationships between both knowledge structure complexity and firm strategic flexibility and firm performance. They defined strategic flexibility as "the ability to precipitate intentional changes and adapt to environmental changes through continuous changes in current stra- 
tegic actions, asset deployment, and investment strategies" (p. 245). Hence, their overall conclusion was that executives' cognitive complexity promotes strategic flexibility which in turn improves firm performance.

\section{Upper Echelons Theory (UET)}

In addition to the executive cognition perspective, we also draw from the upper-echelons theory (UET) to argue that executives' background characteristics affect their selective perception of environmental stimuli (environmental scanning emphasis). UET has two central tenets: first, executives' strategic choices and organizational outcomes are influenced by their values and cognitive base. Second, these values and cognitive base are reflected by observable characteristics such as age, functional background, educational level, socioeconomic roots, financial position and group characteristics (Hambrick \& Mason, 1984; Hambrick, 2007). According to this theory, the observable (e.g. demographic) and cognitive characteristics of executives to a large extent influence their focus of attention. Moreover, UET suggests that executives' strategic choices as well as decisions are largely constrained by cognitive limitations, personal values, and observable demographic characteristics that dictate the amount and type of environmental stimuli they can process and ultimately the types of decisions they make (Carpenter et al., 2004). Since organizational decision-makers are constrained by 'bounded rationality' (March \& Simon, 1958; Cyert \& March, 1963), they tend to search information and pay attention to specific aspects of the environment that 'fits' their characteristics and idiosyncrasies (Dearborn \& Simon, 1958; Thomas, Litschert \& Ramaswamy, 1991).

In the last two decades, an extensive body of empirical work has examined the relationship among executives' background characteristics and various organizational outcomes. Specifically, past studies have empirically examined the relationships among executive demographic characteristics (such as tenure, functional background and educational status) and strategic change (Wiersema \& Bantel, 1992; Boeker, 1997), diversification (Michel \& Hambrick, 1992; Carpenter \& Frederickson, 2001), innovation (Bantel \& Jackson, 1989) and firm performance (Smith, Smith, Sims, O'Bannon \& Scully, 1994; Certo, Lester, Dalton \& Dalton, 2006). Executive tenure and functional background orientation are particularly two major demographic variables that received substantial scholarly attention in the UET literature (Smith et al., 1994; Carpenter et al., 2004). A significant number of the studies have examined firm and position specific average tenure of either the CEO or Top Management Team (TMT) as an important predictor variable (e.g. Katz, 
1982; Miller, 1991). This study seeks to extend the current literature by examining industry-level executive tenure (i.e. number of years in which executives held various managerial position working for different firms within a particular industry) as an important demographic predictor in environmental scanning process.

Similarly, UET researchers have extensively studied executive functional background orientation and heterogeneity as a salient predictor of various organizational outcomes. More specifically, past empirical research has explored the relationship between CEO or TMT functional background heterogeneity and organizational innovation (Bantel \& Jackson, 1989), strategic change (Wiersema \& Bantel, 1992), strategic decisions (Hambrick, Cho, \& Chen, 1996; Jackson, 1992) and firm performance (Carpenter, 2002). Despite the substantial empirical work, the results have in general been inconclusive suggesting a positive impact of functional diversity in some instances and an adverse effect in others. Such a lack of scholarly consensus on the effect of top team functional diversity has recently led some researchers to explore varying conceptualization of the diversity label (Bunderson \& Sutcliffe, 2002; Cannella, Park, \& Lee, 2008). These scholars emphasize the need for a clear conceptual distinction between functional diversity among top team members (which they referred to as 'dominant functional diversity') and functional diversity of each of the top team members (i.e. 'intrapersonal functional diversity'). While the former (dominant functional diversity) focuses on the distribution of different functional background among team members, the later (intrapersonal functional diversity) “...focuses on the extent to which the individuals on a team are narrow functional specialists with experience in a limited range of functions, or broad generalists whose work experiences span a range of functional domains" (Bunderson $\&$ Sutcliffe, 2002, p. 880). In the following section, we specifically discuss these two constructs (i.e. CEO industry tenure and intrapersonal functional diversity) and their proposed relationships with the scope of environmental scanning emphasis.

\section{CEO Industry Tenure}

CEO industry tenure is an important factor affecting information-processing and strategic decision-making patterns in organizations (Hambrick, Geletkanycz \& Frederickson, 1993; Geletkanycz, 1997; Henderson, Miller \& Hambrick, 2006). In this study, we make a clear distinction between CEOs' single and multiple industry tenures. They respectively refer to CEOs' work experience at several firms within a single industry and more than one industry. Here, we focus solely on single industry tenure as a predictor of environmental scanning emphasis. 
We theorize that the length of CEO tenure in a single industry is positively associated with the extent of environmental scanning. We make the argument that the complexity of CEOs' knowledge structure of environmental scanning increases with single industry tenure. CEOs with longer single industry tenure often spend a considerable amount of time working for different firms within the same industry before landing on their current position. Such a 'wealth of experience' generally includes extensive expertise on the dynamics as well as intricacies involved in successfully operating within a particular industry (Spender, 1989). Some studies have shown that longer-tenured executives indeed possess higher level of understanding of the industry's promises, challenges and complexities (Bergh, 2001; Henderson et al., 2006). Longer tenured executives in general are extremely competent in terms of industry-specific technical knowledge and expertise (Henderson et al., 2006). They develop, over time, a better understanding of the linkages among and the influences of various stakeholders on industry behaviors and actions. Long industry tenure also leads to the development of 'industry recipes' or a 'common body of knowledge' (Hambrick, 1982; Spender, 1989). Such in-depth knowledge is strongly tied to understanding supplier and competitor behaviors and customer demand patterns within the industry. Most of them are well aware of the critical success factors determining profitability of firms operating in the particular industry environment. Hence, it is likely that longer industry tenure improves the extent of external environmental scanning in general and specific environmental scanning (task vs. general environment) in particular.

Similarly, CEO industry tenure also influences a CEO's understanding of the impacts of general environment sectors. Significant amounts of the professional experiences executives acquire during the industry tenure are accumulated in their knowledge structures. A CEO's knowledge structure becomes more complex as his/her industry tenure increases. Such complex structures are then used to scan and interpret multiple and diverse environmental stimuli. Consequently, the extent of CEO scanning increases with the complexity of the CEO knowledge structures. This is especially true for the focus or sub-schema of an executive's environment knowledge structure. Previous researchers have argued that schematic information processing can be self-reinforcing. This suggests that executives have the tendency to process more and more task environment information. Hence, we hypothesize that:

$\mathrm{H}_{1}$ : CEO single industry tenure is positively related to the scope environmental scanning. 
More specifically,

$\mathrm{H}_{1}:$ The extent of CEO task environmental scanning increases with the length of his/her single industry tenure.

$\mathrm{H}_{1 \mathrm{~b}}$ : The extent of CEO general environmental scanning increases with the length of his/her single industry tenure.

\section{CEO Intrapersonal Functional Diversity}

The effect of top management team functional diversity on organizational outcomes has been well-researched in the strategic leadership literature (Barsade, Ward, Turner, \& Sonnenfeld, 2000; Certo et al., 2006). In this study, we primarily focus on intrapersonal functional diversity as a predictor of environmental scanning emphasis in organizations. Accordingly, our emphasis will be on empirically testing the relationship between the types of intrapersonal functional diversity (i.e. whether a CEO is a functional specialist or generalist in his/her career experience) and the extent of environmental scanning. We theorize that higher intrapersonal diversity of CEOs is positively associated with the extent of environmental scanning in organizations. CEOs with high intrapersonal diversity (generalists) have substantial exposure in different aspects of the business and therefore are capable of confronting complex strategic issues (Stone \& Tudor, 2005). Generalist CEOs have extensive knowledge and expertise in various functional specialties (e.g. marketing/ sales, administration, finance, accounting, operations) which in turn enables them to scan wide-ranging environmental sectors for relevant information. Therefore, we expect that, due to their extensive functional area exposure, generalist CEOs (with high intrapersonal diversity) engage in broader environmental scanning activity than their specialist (low intrapersonal diversity) counterparts. Specifically, intrapersonal diversity could lead CEOs to emphasize general environment scanning. For example, CEOs with previous experience in marketing, operations, and finance would relatively have greater tendency to scan the different aspects of the general environment such as demographic (related to marketing), technology (related to operations), and economy (related to finance). Hence, we hypothesize that:

$\mathrm{H}_{2}$ : The extent of CEO environmental scanning is positively related to his/her intrapersonal functional diversity.

More specifically, 
$\mathrm{H}_{2 \mathrm{a}}:$ The extent of $C E O$ task environmental scanning is positively related to his/her intrapersonal functional diversity.

$\mathrm{H}_{2 \mathrm{~b}}$ : The extent of CEO general environmental scanning is positively related to his/her intrapersonal functional diversity.

\section{Methods}

\section{Sample}

In order to test the above hypotheses, we selected firms from two considerably different industries, because previous researchers have observed that top executives' knowledge structures vary by industries (Bogner \& Barr, 2000; Nadkarni \& Barr, 2008). For instance, Bogner and Barr (2000) argued that knowledge structures of top executives from hypercompetitive industries are significantly different from those of stable industries. They contend that the differences result from the different experiences of making sense and dealing with the different industries. Similarly, Nadkarni and Barr (2008) found empirical support for their contention that there is dissimilar distribution of executive knowledge structures among different industries.

Accordingly, we selected the Computer and Packaged Foods industries to represent turbulent and stable environments respectively. The Computer industry (SIC Code 3570-3576) often represents rapid technological innovation, changing customer demand, shorter product life cycle and significant product differentiation (Haleblian \& Finkelstein, 1993; Henderson et al., 2006). Packaged foods industry (SIC Code 2000-2090), on the other hand, is characterized by fairly stable market demand, low level of disruptive technological innovation and predictable market share positions among competitors(Geletkanycz, 1997; Henderson et al., 2006). We only selected firms that (1) are based in the United States, (2) are publicly traded in the U.S., and (3) are not highly diversified conglomerates or subsidiaries of a foreign company. We only focused on U.S. based firms because of issues of data availability and difficulty comparing organizational variables across different countries. Highly diversified conglomerates were excluded because their top managers might have very different knowledge structures. For example, in such highly diversified firms, CEOs' knowledge structures of environment are shaped by his previous experiences as well as current social influences from other members of top management teams (Chattopadhyay, Glick, Miller, \& Huber, 1999). Applying the aforementioned criteria, 44 firms in the Computer industry and 46 firms in the Packaged Food industry were included in the final sample of the study. 


\section{Measures and Data Sources}

Extent of environmental scanning: Consistent with previous studies that categorize a firm's environment into task and general environments (Cho, 2006; Daft et al., 1988; Jackson \& Dutton, 1988), we defined the task environment to include competitor, supplier, and customer sectors. The general environment, on the other hand, consists of demographic, economic, political/legal, socio-cultural, and technological sectors. Once the environmental sectors are identified, we used content analysis to measure the extent of environmental scanning emphasis within the sample firms. Content analysis of organizational official documents such as annual reports has been used in the environmental scanning literature to examine executive attention and cognitive patterns (D'Aveni \& MacMillan, 1990; Abrahamson \& Park, 1994; Cho, 2006). Hence, we used the sample firms' FORM 10-K annual reports (including letter to shareholders) to identify a list of words that can be categorized in each of the eight different environmental sectors mentioned above. Two final steps were taken to measure the scope of environmental scanning activity: first, using a specialized Computer Assisted Text Analysis (CATA) software, Concordia (Watts, 2004), we identified a list and frequency of words used in each firm's annual reports that correspond to each of the eight environmental sectors (i.e. customer, supplier, competitor, economic, technological, demographic, political/legal and socio-cultural sectors) for the year 2006. We chose this year due to the extensive availability of quantitative as well as qualitative archival data for each firm in the sample. The list of words we used in this study is consistent with previous literature (D'Aveni and MacMillan, 1990; Cho, 2006).

Second, once the list and frequency of words in the annual report corresponding to each environmental sector was identified, we averaged the total number of words representing each sector to develop a composite measure of task, general, and overall environmental scanning (for instance, we calculated task environment scanning by averaging the number of words representing the customer, competitor and supplier sectors and similarly we averaged the number of words in the annual report representing the five sectors of the general environment specified in the definition above). Similarly, we measured the extent of overall environmental scanning by adding both the frequency of words corresponding to each of the five general environment sectors and the three task environment sectors.

CEO single industry tenure: Following Hambrick et al. (1993) and Stone \& Tudor (2005), we measured CEO single industry tenure by the number of years he/ she spent working as the executive level within the current industry. Dun \& Brad- 
street Reference Book of Corporate Management and annual proxy statements were used to collect data on CEO industry tenure.

Intrapersonal functional diversity: In order to measure CEO intrapersonal functional diversity variable, we first adopted eight dominant functional categories used in previous studies (Cannella et al., 2008; Carpenter \& Fredrickson, 2001). These functional categories are marketing and sales; production and operation; accounting and finance; R\&D and engineering; management and administration; law; personnel and labor relations and others. We then examined each firm's CEO functional background to determine the functional category he/she spent the most time in. Accordingly, if he/she had spent the two-third of his or her career in a specific functional category, we categorize them as "specialists". Conversely, if he/she had spent the last ten years of his/her career in two or more functional categories identified above, we categorize them as "generalists". We chose particularly the two-third threshold because executives serving for such period of time within a single industry will most certainly develop an established career path and expertise (Spender, 1989; Finklestein and Hambrick, 1996). Hence, we use "1" to code specialist CEOs and "2" for all generalist CEOs. CEO intrapersonal functional diversity data were obtained from Dun \& Bradstreet Reference Book of Corporate Management, annual proxy statements of each firm and biographical records located in popular financial websites (e.g. Google Finance).

Control Variables: We controlled for the effects of firm size, CEO firm tenure, total number of words in the annual and letter to shareholders, and CEO network ties. Past research has shown that firm size and resources correlate with firm ability to scan. We measured firm size by the number of employees of sample firms. We measured CEO firm tenure by counting the number of years the CEO spent in an executive position in his/her current firm. Finally, the type and frequency of contacts and social professional ties of executives could potentially affect their environmental scanning activity. Both the environmental scanning and board interlock literatures strongly argue that executives' professional network ties, measured specifically in the number of boards they sit on, influence both the information acquisition and strategy formulation processes (Geletkanycz and Hambrick, 1997; Westphal, Boivie, Chng, 2006). Accordingly, we measured CEO network ties by counting the numbers of board of directors of firms both within and outside of the industry that the CEOs of the sample firms sat on the prior to and including the 2006 calendar year. More specifically, we measured the extent of CEO network ties by counting the number of active board of directors' membership they currently have in 2006 in addition to past appointments before 2006. 


\section{Statistical Analysis}

We used hierarchical multiple regression analysis to test our hypotheses. Prior to proceeding to the analysis, we checked for multivariate assumptions such as linearity, normality and homoscedasticity (Hair, Black, Babin, Anderson \& Tatham, 2006). We also checked for the presence of multicollinearity and examined tolerance and Variance Inflation Factors. Accordingly, we did not find any major violations. We regressed each of the dependent variable on the control and predictor variables.

\section{Results}

Table 1 presents the means, standard deviations, and correlations of the variables in the study. The total sample size for the analysis consists of 44 firms from the Computer industry and 46 firms from Food Processing industry for a total of 90 firms. To correct for a skewed distribution, we used a statistical transformation on the number of employees that is used to measure firm size. Table 2 reports the findings of the hierarchical multiple regression analysis. In general, this study hypothesized that the extent of CEO environmental scanning, task environment scanning, and general environment increase with the length of CEO industry tenure and the breadth of CEO intra functional diversity. More specifically, $\mathrm{H}_{1}$ predicted that the overall extent of CEO environmental scanning generally increases with longer industry tenure. As Model 6 (Table 2) shows, this hypothesis received strong support $(\mathrm{B}=0.165, p<0.05)$. Hence, we found support for the positive relationship between CEOs industry tenure and the extent of overall environmental scanning.

More specifically, $\mathrm{H}_{1 \mathrm{a}}$ hypothesized a positive relationship between CEOs length of industry tenure and the extent of task environment scanning. As can be seen below in Model 2 (Table 2), we found only a marginal support for this hypothesis $(\mathrm{B}=0.167, p<0.10)$. $\mathrm{H}_{1 \mathrm{~b}}$, on the other hand, proposed a positive relationship between CEOs length of industry tenure and general environment scanning. The results of the analysis in Model 4 (Table 2) indicate no statistically significant relationship ( $\mathrm{B}=0.124$, n.s.). Hence, we did not find an empirical support for the relationship between CEOs length of industry tenure and the extent of general environment scanning.

$\mathrm{H}_{2}$ proposed a positive relationship between the extent of CEO overall environmental scanning activity and the level of his/her intrapersonal functional diversity. The results in Model 6 (Table 2) indicate only a marginal statistical support for hypothesis $2(\mathrm{~B}=0.150, p<0.10) . \mathrm{H}_{2 \mathrm{a}}$ specified a positive relationship between 
Table 1

Means, and Standard Deviations, and Correlations $(\mathrm{n}=90)$

\begin{tabular}{|c|c|c|c|c|c|c|c|c|c|c|c|}
\hline & Mean & Std. & 1 & 2 & 3 & 4 & 5 & 6 & 7 & 8 & 9 \\
\hline 1 Firm Size & 3.44 & 4.94 & 1 & & & & & & & & \\
\hline $\begin{array}{l}2 \text { Total words in } \\
\text { Annual Report }\end{array}$ & 3934 & 749.35 & -0.16 & 1 & & & & & & & \\
\hline 3 CEO firm tenure & 8.21 & 8.58 & -0.15 & -0.16 & 1 & & & & & & \\
\hline 4 CEO network ties & 1.46 & 2.12 & 0.024 & 0.01 & -0.17 & 1 & & & & & \\
\hline 5 CEO industry tenure & 14.12 & 11.98 & 0.11 & -0.07 & -0.06 & -0.08 & 1 & & & & \\
\hline $\begin{array}{l}6 \text { CEO intrapersonal } \\
\text { functional diversity }\end{array}$ & 1.29 & 0.64 & $0.20^{\star}$ & -0.10 & $-0.21^{\star}$ & 0.084 & 0.05 & 1 & & & \\
\hline $\begin{array}{l}7 \text { Task Environmental } \\
\text { Scanning }\end{array}$ & 108.77 & 65.83 & 0.13 & $0.50^{\star \star \star}$ & -0.16 & -0.17 & 0.17 & 0.10 & 1 & & \\
\hline $\begin{array}{l}8 \text { General } \\
\text { Environmental } \\
\text { scanning }\end{array}$ & 50.61 & 32.17 & $0.19^{*}$ & $0.55^{\star \star \star}$ & -0.17 & -0.14 & 0.13 & 0.17 & $0.69^{\star \star \star}$ & 1 & \\
\hline $\begin{array}{l}9 \text { External } \\
\text { Environmental } \\
\text { scanning }\end{array}$ & 159.38 & 91.01 & 0.16 & $0.56^{\star \star \star}$ & $-0.18^{*}$ & -0.17 & 0.17 & 0.14 & $0.97^{\star \star \star}$ & $0.85^{\star \star \star}$ & 1 \\
\hline
\end{tabular}

${ }^{\star} p$-value $<0.10 \quad{ }^{\star \star} p$-value $<0.05 \quad{ }^{\star \star \star} p$-value $<0.01$ 
the extent of CEO task environment scanning and the level of his/her intrapersonal functional diversity. The results of our analysis did not provide a statistically significant support for $\mathrm{H}_{2 \mathrm{a}}\left(\mathrm{B}=0.118\right.$, n.s.). Finally, $\mathrm{H}_{2 \mathrm{~b}}$ proposed a positive relationship between the extent of CEO general environment scanning and the level of his/her intrapersonal functional diversity. We found a strong statistically significant support for $\mathrm{H}_{2 \mathrm{~b}}$ as shown in Model 4 in Table $2(\mathrm{~B}=0.184, p<0.05)$.

Overall, the results of our hierarchical multiple regression analysis indicates strong empirical support for the positive relationship between executives' industry tenure and environmental scanning as well as the level of intrapersonal functional diversity (i.e. specialists vs. generalists) and general environment scanning. The significant results explained 45 and 46 percent of the variance in the criterion variables respectively as indicated in model 4 and model 6 .

\section{Discussion}

Environmental scanning is an important step in the strategic formulation process. Executive cognition and the upper echelons literatures have emphasized the importance of knowledge structures in environmental scanning. The extant literature postulates that executives make decisions based on their subjective knowledge structures and underlying cognitive biases. As mentioned earlier, researchers have recently found several benefits of the complexity of executives' knowledge structures (McNamara et al., 2002; Nadkarni \& Narayanan, 2007). They particularly found a positive influence of complex cognitive structures on firm adaptation and profitability.

In this study, we found that CEO industry tenure and intrapersonal functional diversity have positive impacts on the extent of environmental scanning emphasis. Thus, the results suggest that CEOs' knowledge structures become more complex and significantly associated with the length of single industry tenure and intrapersonal functional diversity. Nadkarni and Narayanan (2007) highlighted two possible ways of how complex knowledge structures could increase environmental scanning: cognitive inertia and discounting. They contend that complexity reduces cognitive inertia, because complex schemas increase executives' awareness of and ability to absorb environmental stimuli and simultaneously reduces cognitive discounting. Discounting refers to the discrepancy of executives' subjective knowledge structure and the objective environment. This might suggest that industry tenure and intrafunctional diversity might increase CEOs' ability to reduce cognitive discounting. 
Table 2

Results of Multiple Regression Analysis ${ }^{1}(\mathrm{n}=90)$

\begin{tabular}{|c|c|c|c|c|c|c|}
\hline \multirow[b]{2}{*}{ Variables } & \multicolumn{2}{|c|}{$\begin{array}{c}\text { DV = Task Environment } \\
\text { Scanning }\end{array}$} & \multicolumn{2}{|c|}{$\begin{array}{c}\text { DV }=\text { General } \\
\text { Environment Scanning }\end{array}$} & \multicolumn{2}{|c|}{$\begin{array}{l}\text { DV= Environmental } \\
\text { Scanning }\end{array}$} \\
\hline & Model 1 & Model 2 & Model 3 & Model 4 & Model 5 & Model 6 \\
\hline Firm Size & $0.208^{\star \star}$ & $0.174^{\star}$ & $0.279^{\star \star \star}$ & $0.239^{\star \star \star}$ & $0.249^{\star \star \star}$ & $0.210^{\star \star}$ \\
\hline Total number of words in Annual Report & $0.521^{\star \star \star}$ & $0.544^{\star \star \star}$ & $0.583^{\star \star \star}$ & $0.610^{\star \star \star}$ & $0.583^{\star \star \star}$ & $0.609^{\star \star \star}$ \\
\hline CEO Firm Tenure & -0.088 & -0.053 & -0.064 & -0.019 & -0.086 & -0.045 \\
\hline CEO network ties & $-0.192^{\star \star}$ & $-0.182^{\star \star}$ & $-0.156^{\star}$ & $-.154^{*}$ & $-0.194^{\star \star}$ & $-0.186^{\star \star}$ \\
\hline CEO Industry Tenure & & $0.167^{\star}$ & & 0.124 & & $0.165^{\star \star}$ \\
\hline CEO Intrapersonal functional Diversity & & 0.118 & & $0.184^{\star \star}$ & & $0.150^{*}$ \\
\hline $\mathrm{R}^{2}$ & 0.336 & 0.376 & 0.405 & 0.452 & 0.414 & 0.462 \\
\hline$\Delta \mathrm{R}^{2}$ & & 0.04 & & 0.047 & & 0.048 \\
\hline F change & & $2.69^{\star}$ & & $3.56^{\star \star}$ & & $3.70^{\star \star}$ \\
\hline
\end{tabular}

${ }^{1}$ Standardized regression coefficients are shown $\quad{ }^{\star} p$-value $<0.10 \quad{ }^{\star \star} p$-value $<0.05 \quad{ }^{\star \star \star} p$-value $<0.01$ 
More specifically, we found that the extent of overall scanning, as well as task and general environment scanning emphasis increases with the length of CEO industry tenure and intrapersonal functional diversity. This might suggest that, as hypothesized, knowledge structures over time become more complex as well as focused. The overall increase in complexity is reflected in the significant increase in the overall environmental scanning while increase in focus are reflected in the increased emphasis in task and general environment scanning.

However, the results of this study should be interpreted with caution. We mainly used the schematic information processing and UET theoretical frameworks. Executive cognition researchers have argued that schematic information processing does not apply in novel situations or contexts. Recent research has found that executives' foci of attention are situational. This suggests that executives attention and information processing on environmental scanning is not only guided by his or her previously developed structures related to environment but also other factors. For example, Nadkarni and Barr (2008) found that industry velocity had a positive relationship with managerial focus on the task sector while negatively related with focus on the general sector. Thus executives' attentional focus on task environmental scanning is not only a product of his schematic information processing but also a result of situational factors such as industry velocity that continuously providing the managers with novel information. Thus the study results would be more conclusive if it had also examined the moderating effect of industry velocity and other related factors.

\section{Limitation and Future Research}

We have discussed above the importance of examining situational factors that might have effect on the relationships between CEO tenure, intrafunctional diversity, and scanning behaviors. Another limitation of the study is its cross-sectional approach. The results might have suggested that CEO tenure and intrafunctional diversity have linear relationships with regards to the extent of environmental scanning emphasis. However, there are possibilities that the relationships could also be curvilinear. For example, Henderson et al. (2006) found that CEOs in stable industry lost their touch with the environment after serving for more than 10 years and even faster for CEOs from dynamic industries. Hence, this might suggest that there is curvilinear relationship between CEO tenure and his or her environmental scanning emphasis.

The findings of this study provide a number of future research implications. Future research might want to examine the interaction effect of industry velocity with 
executive background characteristics. We also did not examine a potential interaction effect of executives' single industry tenure and intrafunctional diversity on environmental scanning emphasis. This study only examined the differentiation aspect of knowledge structure complexity. According to Walsh (1995), schematic complexity relates to both differentiation and integration (connectedness). Differentiation refers to the variety of concepts embedded in schemas. Integration refers to the degree of connectedness of various concepts contained in knowledge structures. We did not examine the impact of industry tenure and intrapersonal functional diversity on the integration aspect of knowledge structures. The integration aspect reflects managers' understanding of the causal logics of various strategic variables, i.e. relationship between technology and competition, contained in a schema. The examination is important because causal reasoning is the basis of decision making (Fiske \& Taylor, 1991).

Future researchers can study relationship between executive's attentional focus and environmental scanning behavior. The attention-based view of the firm theorizes that individual decision-makers' actions are generally driven by their focus of attention and that such decisions and actions are influenced by the situational contexts that surround these decision-makers (Ocasio, 1997). Proponents of the attention-based view emphasize the important role of focused attention of decisionmakers in articulating the strategic direction as well as guiding routine tasks of the organization. In this study's context, the attention-based view of the firm would suggest that executives' focus of attention drives their environmental scanning patterns and that their scanning activities in turn shape strategic formulation (Cho \& Hambrick, 2006; Nadkarni \& Barr, 2008). In addition, based on the premise of situated attention articulated in the attention-based view of the firm (Ocasio, 1997), executives' environmental scanning behavior may vary depending on the type of environment (i.e. stable or turbulent) their organizations operate in. Thus, future researchers should examine the impacts of industry tenure and intra diversity on the integration and focus aspects of knowledge structures as well as the moderating impacts of the environmental turbulence and stability.

\section{End Note}

1. We used the concept of CEO environmental scanning and firm-level scanning interchangeably in this study. The majority of the scanning literature seems to argue that the CEO, along with his/her executive team, gather, analyze and interpret environmental stimuli in order to formulate effective business strategy (e.g. Aguilar, 1967; Hambrick, 1981; Daft \& Weick, 1984; Garg et al., 2003). 


\section{References}

Abrahamson, E., \& Park, C. (1994). Concealment of negative organizational outcomes: An agency theory perspective. Academy of Management Journal, 37, 1302-1334.

Aguilar, F. J. (1967). Scanning the business environment. New York: Macmillan.

Bantel, K. \& Jackson, S. (1989). Top management and innovations in banking: Does the composition of the top team make a difference? Strategic Management Journal, 10, 107-124.

Barsade, S., Ward, A., Turner, J., \& Sonnenfeld, J. (2000). To your heart's content: A model of affective diversity in top management teams. Administrative Science Quarterly, 45(4), 802-836.

Baum, J. \& Wally, S. (2003). Strategic decision speed and firm performance. Strategic Management Journal, 24(11), 1107-1129.

Bergh, D. (2001). Executive retention and acquisition outcomes: A test of opposing views on the influence of organizational tenure. Journal of Management, 27, 603-622.

Boeker, W. (1997). Strategic change: The influence of managerial characteristics and organizational growth. Academy of Management Journal, 40(1), 152-170.

Bogner, W. \& Barr, P. (2000). Making sense in hypercompetitive environments: A cognitive explanation for the persistence of high velocity competition. Organization Science, 11(2), 212-226.

Bunderson, J. \& Sutcliffe, K. (2002). Comparing alternative conceptualizations of functional diversity in management teams: process and performance effects. Academy of Management Journal, 45(5), 875-893.

Cannella, A., Park, J.-H., \& Lee, H.-U. (2008). Top management team functional background diversity and firm performance: Examining the roles of team member colocation and environmental uncertainty. Academy of Management Journal, 51(4), 768-784.

Carpenter, M. (2002). The implications of strategy and social context for the relationship between top team management heterogeneity and firm performance. Strategic Management Journal, 23(3), 275-284.

Carpenter, M. \& Fredrickson, J. (2001). Top management teams, global strategic posture, and the moderating role of uncertainty. Academy of Management Journal, 44(3), 533-545.

Carpenter, M., Geletkanycz, M., \& Sanders, W. (2004). Upper echelons research revisited: Antecedents, elements, and consequences of top management team composition. Journal of Management, 30(6), 749-778. 
Certo, S., Lester, R., Dalton, C., \& Dalton, D. (2006). Top management teams, strategy and financial performance: A meta-analytic examination. Journal of Management Studies, 43(4), 813-839.

Chattopadhyay, P., Glick, W., Miller, C., \& Huber, G. (1999). Determinants of executive beliefs: Comparing functional conditioning and social influence. Strategic Management Journal, 20(8), 763-789.

Child, J. (1972). Organizational structure, environment, and performance: The role of strategic choice. Sociology, 6, 1-22.

Cho, T. (2006). The effects of executive turnover on top management team's environmental scanning behavior after an environmental change. Journal of Business Research, 59, 1142-1150.

Cho, T. \& Hambrick, D. (2006). Attention as the mediator between top management team characteristics and strategic change: The case of airline deregulation. Organization Science, 17(4), 453-469.

Cyert, R., \& March, J. (1963). A behavioral theory of the firm. Englewood Cliffs, NJ: Prentice Hall.

Daft, R. L., Sormunen, J., \& Parks, D. (1988). Chief executive scanning, environmental characteristics, and company performance: An empirical study. Strategic Management Journal, 9(2), 123-139.

Daft, R. \& Weick, K. (1984). Toward a model of organizations as interpretation systems. Academy of Management Review, 9(2), 284-295.

D'Aveni, R., \& MacMillan, I. (1990). Crisis and the content of managerial communications: A study of the focus of attention of top managers in surviving and failing firms. Administrative Science Quarterly, 35, 634-657.

Dearborn, D., \& Simon, H. (1958). Selective perception: A note on the department identification of executives. Sociometry, 21, 140-144.

Eden, C., Ackermann, F., \& Cropper, S. (1992). The analysis of cause maps. Journal of Management Studies, 29(3), 309-324.

Finkelstein, S., \& Hambrick, D. (1990). Top-management-team tenure and organizational outcomes: The moderating role of managerial discretion. Administrative Science Quarterly, 35(3), 484-503.

Finklestein, S. \& Hambrick, D. (1996). Strategic leadership: Top executives and their effects on organizations. St. Paul, MN: West Publishing Company.

Fiske, S. T., \& Taylor, S. E. (1991). Social cognition. New York: McGraw-Hill.

Garg, V., Walters, B., \& Priem, R. (2003). Chief executive scanning emphasis, environmental dynamism, and manufacturing firm performance. Strategic Management Journal, 24, 725-744. 
Geletkanycz, M. (1997). The salience of 'culture's consequences': The effects of cultural values on top executive commitment to the status quo. Strategic Management Journal, 18(8), 615-634.

Geletkanycz, M. \& Hambrick D. (1997). The external ties of top executives: Implications for strategic choice and performance. Administrative Science Quarterly, $42,654-681$.

Hair, Jr., J., Black, W., Babin, B., Anderson, R., \& Tatham, R. 2006. Multivariate data analysis. 6th Ed. Upper Saddle River, NJ: Pearson-Prentice Hall.

Haleblian, J., \& Finkelstein, S. (1993). Top management team size, CEO dominance, and firm performance: The moderating roles of environmental turbulence and discretion. Academy of Management Journal, 36(4), 844-863.

Hambrick, D. (2007). Upper echelons theory: An update. Academy of Management Review, 32(2), 334-343.

Hambrick, D., Cho, T., \& Chen, M.-J. (1996). The influence of top management team heterogeneity on firms' competitive moves. Administrative Science Quarterly, 41(4), 659-684.

Hambrick, D., Geletkanycz, M., \& Fredrickson, J. (1993). Top executive commitment to the status quo: Some tests of its determinants. Strategic Management Journal, 14(6), 401-418.

Hambrick, D., \& Mason, P. (1984). Upper echelons: The organization as a reflection of its top managers. Academy of Management Review, 9(2), 193.

Hambrick, D. (1982). Environmental scanning and organizational strategy. Strategic Management Journal, 3, 159-174.

Hambrick, D. (1981). Specialization of environmental scanning activities among upper level executives. Journal of Management Studies, 18(3), 299-320.

Henderson, A., Miller, D., \& Hambrick, D. (2006). How quickly do CEOs become obsolete? Industry dynamism, CEO tenure, and company performance. Strategic Management Journal, 27(5), 447-460.

Jackson, S. (1992). Consequences of group composition for the interpersonal dynamics of strategic issue processing. In G. B. McCabe (Ed.), Advances in Strategic Management 8, 345-382.

Jackson, S., \& Dutton, J. (1988). Discerning threats and opportunities. Administrative Science Quarterly, 33(3), 370-387.

Janis, I. L. (1972). Victims of groupthink. New York: Houghton Mifflin.

Katz, R. (1982). The effects of group longevity on project communication and performance. Administrative Science Quarterly, 27(1), 81. 
Kiesler, S., \& Sproull, L. (1982). Managerial response to changing environments: Perspectives on problem sensing from social cognition. Administrative Science Quarterly, 27(4), 548-570.

March, J., \& Simon, H. (1958). Organizations. New York: Wiley.

McNamara, G., Luce, R., \& Tompson, G. (2002). Examining the effect of complexity in strategic group knowledge structures on firm performance. Strategic Management Journal, 23(2), 153-170.

Michel, J., \& Hambrick, D. (1992). Diversification posture and top management team characteristics. Academy of Management Journal, 35(1), 9-37.

Miles, R., \& Snow, C. (1978). Organizational strategy, structure and process. New York: McGraw-Hill.

Miller, D. (1991). Stale in the saddle: CEO tenure and the match between organization and environment. Management Science, 37(1), 34-52.

Nadkarni, S., \& Barr, P. (2008). Environmental context, managerial cognition, and strategic action: an integrated view. Strategic Management Journal, 29(13), 1395-1427.

Nadkarni, S., \& Narayanan, V. (2005). Validity of the structural properties of textbased causal maps: An empirical assessment. Organizational Research Methods, 8(1), 9-40.

Nadkarni, S., \& Narayanan, V. (2007). Strategic schemas, strategic flexibility, and firm performance: The moderating role of industry clockspeed. Strategic Management Journal, 28(3), 243-270.

Neisser, U. (1976). Cognitive psychology. Englewood Cliffs, NJ: Prentice-Hall.

Ocasio, W. (1997). Towards an attention based view of the firm. Strategic Management Journal, 18, 187-206.

Sawyerr, O. (1993). Environmental uncertainty and environmental scanning activities of Nigerian manufacturing executives: A comparative analysis. Strategic Management Journal, 14, 287-299.

Simon, H. (1959). Theories of decision-making in economics and behavioral science. American Economic Review, 49(3), 253-283.

Smith, K., Smith, K., Sims Jr, H., O'Bannon, D., \& Scully, J. (1994). Top management team demography and process: The role of social integration and communication. Administrative Science Quarterly, 39(3), 412-438.

Spender, J. C. (1989). Industry recipes: The nature and sources of managerial judgment. Oxford: Basil Blackwell. 
Stone, W. \& Tudor, T. (2005). The effects of functional background experience, industry experience, generic executive management experience on perceived environmental uncertainty and firm performance. Advances in Competitiveness Research, 13(1), 1-8.

Sutcliffe, K., \& Huber, G. (1998). Firm and industry as determinants of executive perceptions of the environment. Strategic Management Journal, 19(8), 793-807.

Sutcliffe, K. (1994). What executives notice: Accurate perceptions in top management teams. Academy of Management Journal, 37(5), 1360-1378.

Thomas, J., Clark, S., \& Gioia, D. (1993). Strategic sensemaking and organizational performance: Linkages among scanning, interpretation, action, and outcomes. Academy of Management Journal, 36(2), 239-270.

Thomas, A., Litschert, R., \& Ramaswamy, K. (1991). The performance impact of strategy-manager coalignment: An empirical examination. Strategic Management Journal, 12(7), 509-522.

Walsh, J. (1995). Managerial and organizational cognition: Notes from a trip down memory lane. Organization Science, 6(3), 280-321.

Watts, R. J. (2004). Concordance. Retrieved November 20, 2008, from www.concordancesoftware.co.uk/

Weick, K. (1979). Cognitive processes in organizations. Research in Organizational Behavior, 1, 41-74.

Westphal, J., Boivie S., Chng, D. (2006). The strategic impetus for social network ties: Reconstituting broken CEO friendship ties. Strategic Management Journal, 27, 425-445.

Wiersema, M., \& Bantel, K. (1992). Top management team demography and corporate strategic change. Academy of Management Journal, 35(1), 91-121.

\section{Biographical Sketch of Authors}

Arifin Angriawan is an Assistant Professor of Management at Purdue University Calumet, Hammond, Indiana. His research interests include the impacts of top management team characteristics on firm strategic decisions and financial performance, determinants of executive beliefs, and e-commerce issues.

Michael A. Abebe is an Assistant Professor of Management at the University of Texas-Pan American, Edinburg, Texas. His research interests include organizational change and renewal, executive cognition, strategic decision-making process and social issues in minority entrepreneurship. 


\section{Journal \\ of}

Sam Houston State University

A Member of The Texas State University System

$\begin{array}{ll}\text { Charlie Amato, Chairman } & \text { San Antonio } \\ \text { Donna N. Williams, Vice Chairman } & \text { Arlington } \\ \text { Jaime R. Garza } & \text { San Antonio } \\ \text { Kevin J. Lilly } & \text { Houston } \\ \text { Ron Mitchell } & \text { Horseshoe Bay } \\ \text { David Montagne } & \text { Beaumont } \\ \text { Trisha Pollard } & \text { Bellaire } \\ \text { Rossanna Salazar } & \text { Austin } \\ \text { Michael Truncale } & \text { Beaumont } \\ \text { Chris Covo, Student Regent } & \text { San Marcos } \\ \text { Brian McCall, Chancellor } & \text { Austin }\end{array}$

\section{Business Strategies}

Gibson D. Lewis Center

for

Business and Economic Development 